\title{
CONTENT MARKETING JAKO JEDEN Z KLUCZOWYCH ELEMENTÓW NOWOCZESNEJ STRATEGII MARKETINGOWEJ
}

\author{
Luiza Skrobich \\ Politechnika Częstochowska
}

\begin{abstract}
Streszczenie: Dynamicznie zmieniające się otoczenie wpływa na rozwój dotychczasowych oraz powstawanie nowych strategii i - w konsekwencji - technik marketingowych. Jedną z nich jest właśnie content marketing, który to zakłada tworzenie unikalnych treści pod kątem wybranej grupy docelowej z założeniem obustronnej komunikacji z klientem. Celem niniejszego artykułu jest wskazanie na content marketing jako na jeden z kluczowych elementów nowoczesnej strategii marketingowej, która zakłada zaangażowanie i tworzenie wartości dla potencjalnych klientów. Rozważanie teoretyczne - oparte na internetowych źródłach literaturowych ze względu na niewielką ilość pozycji książkowych na ten temat - wzbogacono praktycznym przykładem efektywnego wykorzystania tej techniki przez przedsiębiorstwa, które zawdzięczają odpowiedniej - nowoczesnej - strategii marketingowej swoją bardzo dobrą pozycję konkurencyjną.
\end{abstract}

Słowa kluczowe: content marketing, marketing przychodzący, nowoczesna strategia marketingowa, zarządzanie przedsiębiorstwem

DOI: 10.17512/znpcz.2016.2.07

\section{Wprowadzenie}

Każda strategia marketingowa ma za zadanie zapewnić przetrwanie i rozwój organizacji w dynamicznie zmieniającym się otoczeniu. Nastawiona jest ona na realizację celów przedsiębiorstwa zgodnie z jego misją, a szczególnie na główny jego cel, jakim jest maksymalizacja zysków. Niezbędnym jednak warunkiem jest skuteczne jej zintegrowanie z ogólną strategią biznesową firmy.

Celem niniejszego artykułu jest ukazanie content marketingu jako nowoczesnej techniki marketingowej, która pozwala na zbudowanie dużej przewagi konkurencyjnej. Firmy upatrują wielu korzyści ze stosowania kampanii wzbogaconych o content marketing. Jest to nowy kanał komunikacji z klientami, który pozwala na lepszą identyfikację oferty i przyjazne nastawienie do klienta. Co więcej - pozwala na realny wzrost ruchu na stronie, a przez to podnosi świadomość marki i sprzedaży. To dlatego właśnie content marketing jest jedną z najszybciej i najprężniej rozwijających się gałęzi marketingu (Chorowiec 2014, s. 2).

Artykuł został podzielony na dwie części - pierwsza opisuje technikę content marketingu od strony teoretycznej, druga zaś wskazuje, poprzez analizę dobrych praktyk, zagadnienie od strony praktycznej - na przykładzie wybranych firm (Nike, Lego, Red Bull oraz Coca-Cola). 


\section{Content marketing jako technika strategii inbound marketingu}

Jednym z komponentów wchodzących w zakres przedmiotowy strategii marketingowej jest wybór instrumentów marketingu mix. Instrumenty wchodzące w skład tej kompozycji to: produkt, cena, dystrybucja i promocja. Każdy z tych elementów jest niezwykle istotny, a wszystkie razem muszą być zintegrowane i tworzyć efekt synergii. Podstawą nowoczesnej strategii marketingowej jest nastawienie na uzyskanie w innowacyjny sposób następujących efektów (Velocity 2012):

- większa sprzedaż,

- lojalność i zaufanie klientów,

- rozpoznawalność/znajomość marki.

W związku z tym, że tradycyjne metody nie zawsze spełniają swoje zadanie, powstają nowe, nieszablonowe techniki i narzędzia marketingowe, które to pozwalają skutecznie osiągać założone efekty. Niezmienny pozostaje warunek gwarancji sukcesu - odpowiednie pozyskanie oraz utrzymanie poprzez satysfakcję i pełne zadowolenie klientów.

Jedną z nowoczesnych strategii marketingowych jest tzw. inbound marketing, czyli tzw. „marketing przychodzący”. Koncepcja ta polega ona podejmowaniu takich działań, które sprawią, iż potencjalni klienci sami znajdą nadawcę danego przekazu. Cztery podstawowe filary tej strategii to (Zys 2012):

- statystyki strony (dążenie do zwiększenia liczby odwiedzin na stronie internetowej),

- przywiązanie do marki (transformacja zaangażowania w lojalność wobec marki),

- konwersja (przekształcenie odwiedzającego stronę w stałego klienta firmy),

- mierzenie efektywności (np. poprzez wykorzystanie odpowiednich wezwań do działania tzw. call to action oraz kodów promocyjnych).

Strategia ta przeżywa w ostatnich latach ogromny wzrost zainteresowania. Firmy zauważyły, że szum informacyjny spowodował niechęć i spadek zainteresowania tradycyjnym marketingiem, który to niejako „nachodził” konsumenta, często w nieodpowiednim miejscu i czasie (Gabryś 2013). Inbound marketing to remedium na te problemy, co potwierdzają statystyki - zwiększające się zainteresowanie strategią, większa liczba organizacji wdrażających jej zasady, pozytywny odbiór konsumentów (Winter 2014). Techniki tej strategii wykorzystują potencjał Internetu oraz chęć pozyskiwania szybkich i sprawdzonych informacji, czyli idealnie wpisują się w styl życia współczesnego człowieka, szczególnie generacji Y. Głównymi technikami inbound marketingu są (Oruba 2014):

- promocja w social media (mediach społecznościowych) np. Facebook, YouTube, Twitter, Snapchat;

- prowadzenie bloga branżowego;

- optymalizacja dla wyszukiwarek internetowych (SEO, tzw. pozycjonowanie);

- content marketing, czyli tworzenie i rozpowszechnianie w Internecie unikalnych wiarygodnych, a także użytecznych i wartościowych treści (np. w formie e-booków, video, case study, prezentacji on-line, infografik, tutoriali, podcastów, aplikacji mobilnych czy webinarium), które zawierają przydatne (często również zabawne) informacje dla internautów. 
Instytut Content Marketingu definiuje: „Content marketing to technika marketingowa polegająca na tworzeniu oraz rozpowszechnianiu istotnych i cennych treści, dążąca do przyciągnięcia, pozyskania i zaangażowania jasno zdefiniowanej grupy odbiorców docelowych - w celu zmotywowania klienta do działań przynoszących zysk" (cyt. za Content Marketing Institute). Autorzy innych definicji wskazują, że istotną przewagą tej techniki marketingowej jest zapewnienie odbiorcom pożądanego doświadczenia, wykluczając poczucie nachalnego czy mało wartościowego przekazu reklamowego. Ponadto jej ogromnym walorem jest różnorodność form nośników efektywnie skupiających uwagę klienta (film, fotografie, prezentacje, nagrania, e-booki, infografiki itd.) oraz możliwość odbioru na różnych urządzeniach, w tym laptopach, tabletach, smartfonach itp. Technika ta jest marketingiem, który przyciąga, intryguje i angażuje dzięki odpowiednim - istotnym, uczącym, przekonującym, pomocnym czy zabawnym - informacjom (MarketingProfs 2015). Musi ona jednak być świadomie przyjętym i konsekwentnie propagowanym sposobem myślowym. Warto w tym miejscu zaznaczyć, iż istnieje szereg korzyści wynikających ze stosowania content marketingu (Maczuga i in. 2014):

- Zaangażowanie i innowacyjność klientów: 1 osoba, która z własnej woli subskrybuje blog firmowy, jest cenniejszym leadem niż 100 odbiorców tradycyjnego mailingu, ponieważ kreuje wizerunek firmy - eksperta, innowatora w branży, co może przełożyć się na efekt marketingu szeptanego.

- Optymalizacja dla wyszukiwarek internetowych: ciekawe treści wpływają na statystyki, które odpowiadają za pozycjonowanie strony internetowej.

- Rozwój kultury opartej na wiedzy: content marketing inicjuje i propaguje tworzenie oraz rozpowszechnianie wartościowych, ciekawych i sprawdzonych treści w Internecie.

- Lepsze wykorzystanie zasobów firmy: możliwość efektywniejszego spożytkowania posiadanych zasobów, np. wiedzy, czasu, kompetencji czy sprzętu technicznego.

W świetle przedstawionych rozważań content marketing wydaje się idealnym rozwiązaniem, szczególnie dla przedsiębiorstw, której grupą docelową są ludzie pokolenia cyfrowego. Warto zauważyć, że oprócz zadbania o odpowiednie treści trzeba również bardzo zaangażować się w proces ich rozpowszechnienia, aby dotarły one do wybranej i zarazem jak największej liczby odbiorców, czyli o tzw. dystrybucję treści (Kubik b.r.).

\section{Content marketing w strategii marketingowej organizacji}

Jednym ze sposobów na realizowanie strategii content marketingu jest zdobycie odpowiednich kompetencji wewnątrz zespołu marketingowego. Zaletą takiego rozwiązania jest pełna kontrola nad przebiegiem i realizacją działania. Content marketing wymaga stałego generowania treści, co jest bardzo pracochłonne; potrzeba także systematyczności, dużej wiedzy merytorycznej i umiejętności dopasowywania treści do odpowiedniego miejsca, formy i czasu. $Z$ tych względów organizacje mogą zdecydować się na zlecenie firmie zewnętrznej, tj. agencji marketingowej, działań w tym zakresie. Atutem outsourcingu jest także zapewnie- 
nie wysokiej jakości usługi dzięki specjalizacji danej firmy oraz fakt, iż w praktyce taka forma okazuje się tańszym rozwiązaniem, a ryzyko osłabienia lojalności partnera wraz $\mathrm{z}$ upływem czasu jest znikome.

Pierwszym krokiem do skutecznego wdrożenia content marketingu jest określenie swoich celów biznesowych, np. (Chorowiec 2014, s. 20):

- wzrost sprzedaży,

- budowanie zaufania i wiarygodności,

- zwiększenie świadomości marki i produktu,

- edukacja odbiorców dotycząca nowego produktu,

- zainspirowanie do działania.

Kolejnym krokiem jest adekwatne przygotowanie do działań - najpierw należy określić, gdzie w przestrzeni internetowej przebywa potencjalny klient (np. Google, social media, blogi branżowe). Następnie trzeba dokładnie zaplanować akcję content marketingowa (stworzenie harmonogramu działań) - opracować treści, wybrać typ publikacji oraz wytypować odpowiedni czas kampanii (uwzględniający np. sezonowość, trendy). Należy także zsynchronizować wszystkie działania w Internecie $\mathrm{z}$ akcją content marketingowa i informować na bieżąco osoby zainteresowane (np. fani na Facebooku czy obserwujący na Instagramie) o nowościach, ciekawostkach itp. Następnym etapem jest przystąpienie do działania, tj. przygotowanie treści najlepiej dopasowanych do odbiorców, tak aby przyniosły realną korzyść - muszą one być wartościowe i prezentować wysoki poziom jakości. Dodatkowo warto zadbać, aby były łatwo dostępne i przystępne w odbiorze oraz aby naturalnie wpływały na duże zaangażowanie odbiorców. Niezbędne jest także zadbanie o osiągnięcie możliwie najwyższej pozycji w wynikach wyszukiwarek internetowych. Na tym etapie można przystąpić do publikacji treści. Potem trzeba jeszcze zadbać o promowanie treści - wybrane sposoby promowania przedstawia Rysunek 1 .

\section{PROMUJ SWOJE TREŚCI}

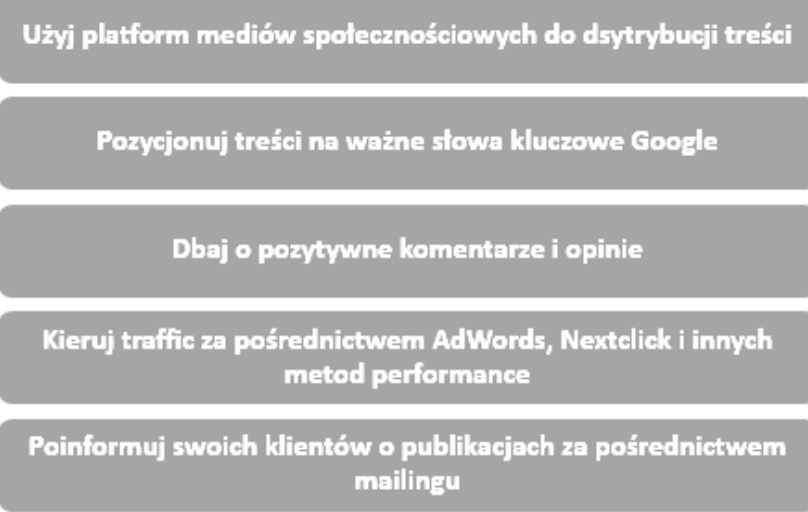

Rysunek 1. Sposoby promowania treści w strategii content marketingowej

Źródło: (Chorowiec 2014, s. 2) 
Ostatnim elementem jest weryfikacja efektów - konieczne jest obliczenie zwrotu z inwestycji akcji w przeliczeniu na ruch i faktyczną sprzedaż, warto także zmierzyć konwersję ruchu generowanego przez treść oraz sprawdzić wskaźniki w Google Analytics (Chorowiec 2014, s. 19-21).

Ogromnym sukcesem firmy wydaje się moment, w którym klienci są na tyle zaangażowani, że tworzą i udostępniają własne treści (user-generated content), nawiązujące do produktu, historii lub akcji (Kamińska b.r.). Takie działanie wzbudza jeszcze większe zaufanie, przez co przyczynia się do zwiększenia liczby decyzji zakupowych (Potępa 2015).

\section{Content marketing w praktyce na przykładzie wybranych firm - Nike, Lego oraz Red Bull}

Istnieje sześć składników idealnego contentu - naturalne (brak charakteru sprzedażowego), zaufane (łatwo identyfikowalne źródło), wirusowe (angażujące w rozpowszechnianie), multimedialne (interaktywne), użyteczne (przydatne dla odbiorcy) oraz skanowalne, czyli łatwe do zapoznania się (Winter 2014). Firmy, które z powodzeniem realizują strategię marketingową opartą o content, nie zawsze perfekcyjnie wpisują się we wskazane elementy. Zastosowanie kilku wybranych jest już wystarczające, aby odnieść sukces na rynku.

Pierwszy przykład to akcja content marketingowa z połowy lat sześćdziesiątych firmy Nike. Jej założyciel - Bill Bowerman - poprzez wydanie 19-stronicowej broszury zatytułowanej „Jogging” przyczynił się do upowszechnienia biegania, jako sposobu na osiągnięcie sprawności fizycznej. Broszura nie nawiązywała bezpośrednio do produktów firmy, ale skłoniła do inicjatywy, zmiany stylu życia i tym samym przyczyniła się do wzrostu zapotrzebowania na produkty oferowane przez Nike (edukacja klientów o korzyściach płynących z używania produktu) (Korach 2015).

Kolejnym przykładem niesamowicie efektownego działania w ramach content marketingu jest firma Lego. Scenariusze Lego posiadają dedykowaną mikrostronę internetową, która zawiera opis fabuły i bohaterów oraz gry on-line, filmy, ankiety, konkursy, jak i linki do sprzedaży (Rysunek 2). Każdy nowy scenariusz natomiast powiązany jest $\mathrm{z}$ filmem na kształt serialu, który emitowany jest $\mathrm{w}$ telewizji kablowej oraz na oficjalnej stronie firmy. Niedawno seria Lego Chima związana była także z powstaniem nowej kreskówki emitowanej na Cartoon Network. Inną ciekawą inicjatywą firmy jest strona Click - platforma aktywizująca fanów do dzielenia się pomysłami ma konstrukcję Lego (Maczuga i in. 2014, s. 11-12).

Firma Red Bull jest następną firmą, której dobre praktyki warto wyróżnić. Wydaje ona od 2007 roku comiesięczny magazyn „The Red Bulletin” (Rysunek 3), który ma obecnie ponad 5 milionów prenumeratorów. Publikacje Red Bull są bardzo obszerne, zarówno jeśli mowa o mediach, jak i kanałach czy formatach. W ich skład wchodzą aplikacje mobilne, telewizja internetowa, sieci społecznościowe, wersje drukowane, spływ wiadomości (newsfeed), video, a także film pełnometrażowy. Firma jest właścicielem 900 domen o różnych nazwach, w 36 językach. Red Bull stawia na rozrywkę, zdając sobie sprawę z siły contentu wirusowego. Rozmiar wdrażania strategii treści jest na tyle duży, że firma założyła oddzielną spółkę medialną (Maczuga i in. 2014, s. 13). 


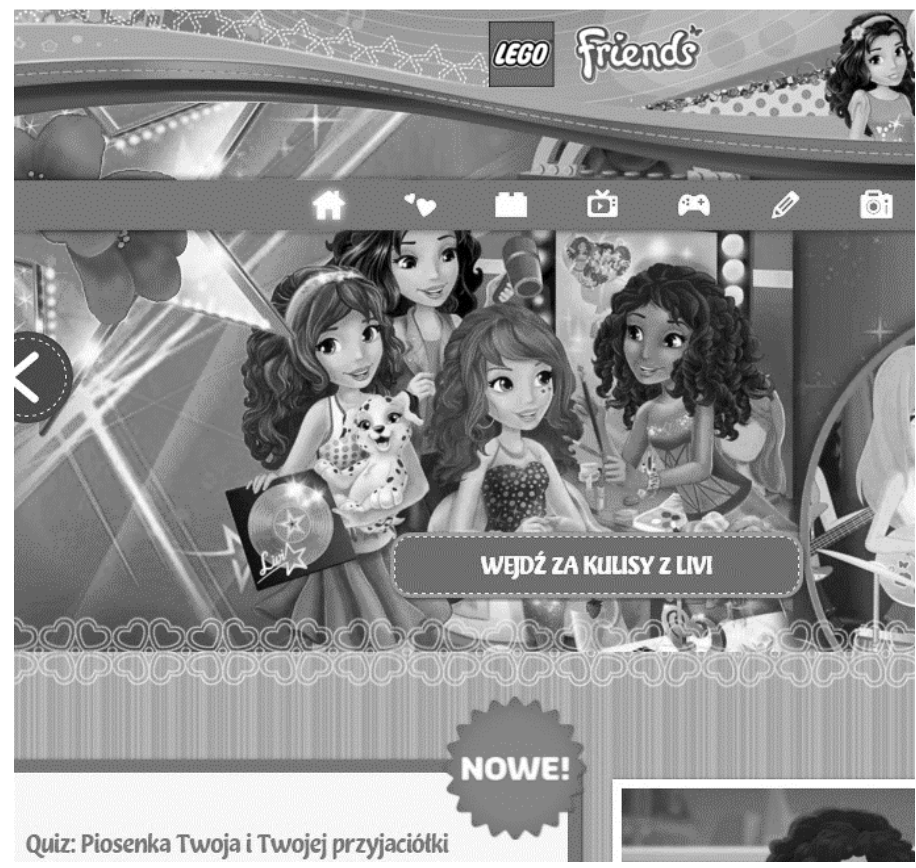

Rysunek 2. Mikrostrona internetowa dedykowana Lego Friends

Źródło: (www.lego.com/pl-pl/friends)

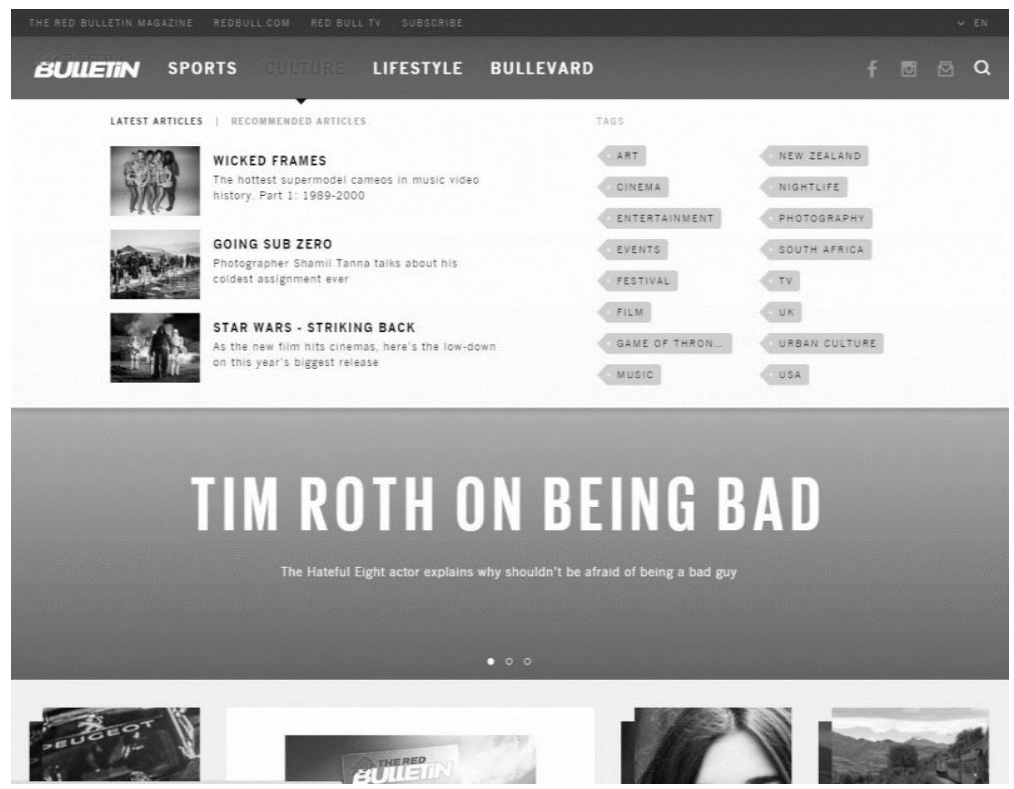

Rysunek 3. Strona internetowa „The Red Bulletin”

Źródło: (www.redbulletin.com/int/en) 
Ostatni przykład to firma, która jest jedną z najbardziej rozpoznawalnych marek na świecie oraz posiada najwięcej fanów na Facebooku (ponad 96 milionów), mianowicie Coca-Cola. W 2011 roku zamieściła ona na swoim kanale YouTube filmy, w których, dzięki serii zabawnych i ciekawych obrazów (w których przeważały kolory marki biały, czerwony i czarny), pokazała kreatywność i mobilność swojej słynnej strategii marketingowej o nazwie Content 2020. Barwność, humor i pomysłowość treści zamieszczonych w sieci internetowej spowodowała stałe zaangażowanie klientów oraz rozpowszechnianie przez nich informacji do jeszcze większego grona odbiorców. Drugą cechą wybranej strategii był tzw. linked content, czyli sprawienie, żeby wszystkie treści były istotne oraz związane z celami i wartościami marki. Tym sposobem firma przeszła do dynamicznego sposobu opowiadania, pozwalając konsumentom na interakcję (Strykowski, Kamińska 2015, s. 15).

Powyższa analiza dobrych praktyk pokazuje bogactwo narzędzi content marketingu, które pozwalają na utworzenie niepowtarzalnej i efektownej kampanii, choć trzeba pamiętać, iż każde $\mathrm{z}$ nich ma swoje mocne i słabe strony. Ponadto należy odpowiednio przemyśleć swój wybór pod kątem potencjału, dobrych i złych praktyk, a także nakładu kosztów oraz możliwości realizacji i zmierzenia efektów.

\section{Podsumowanie}

Reasumując, warto zauważyć, że praktyki związane z content marketingiem nie są zarezerwowane tylko dla międzynarodowych korporacji - można je równie efektywnie przenieść do MŚP. Szczególnie mając na uwadze fakt, iż są one bardzo ekonomiczne oraz łatwo dostępne. Warto inwestować w tę technikę, ponieważ większość z firm zauważa realne i mierzalne korzyści, tj. większe zaangażowanie ze strony klientów, wzrost sprzedaży oraz liczby subskrybentów czy poleceń (Maczuga $\mathrm{i}$ in. 2014, s. 81).

Działania w ramach content marketingu obejmują wiele różnorakich inicjatyw i aktywności, a wszystkie one - odpowiednio zaplanowane i wdrożone - obfitują w pozytywne skutki, zarówno dla firmy, jak i klienta. Dlatego jest to coraz bardziej doceniany element każdej strategii marketingowej, zaś w nowoczesnych strategiach content marketing to kluczowy element, a nawet więcej - nieodłączny ich komponent.

Ogrom możliwości rozwoju potencjału narzędzi content marketingu wiąże się z koniecznością stałego kształcenia i nieustanną obserwacją wszelkich działań na tym polu. Już dziś można przewidzieć, że takie narzędzia jak media społecznościowe, blogi czy webinaria umocnią swoją rolę i staną się jeszcze popularniejsze wśród marketerów. Zarówno w teraźniejszości, jak i w przyszłości content marketing będzie skutecznym i pożądanym sposobem na realizowanie celów biznesowych organizacji. 


\section{Literatura}

1. Chorowiec W. (2014), Content marketing - zobacz, jak to robia najlepsi!, www.iab.org.pl/ wp-content/uploads/2014/01/12.07.-CONTENT-MARKETING-ZOBACZ-JAK3.pdf (dostęp: 05.01.2016).

2. Content Marketing Institute, Launch your own Content Marketing Program Why. Who. How, www.contentmarketinginstitute.com/launch-content-marketing-program (dostęp: 03.01.2016).

3. Gabryś K. (2013), Zarządzanie wiedza i komunikacja - priorytetem współczesnej organizacji, „Zeszyty Naukowe Politechniki Częstochowskiej. Zarządzanie” nr 12, s. 85-86, Sekcja Wydawnictw Wydziału Zarządzania Politechniki Częstochowskiej, Częstochowa.

4. Kamińska P. (b.r.), 5 sposobów na content marketing dla nudnych marek, www.whitepress.pl/ baza-wiedzy/86/5-sposobow-na-content-marketing-dla-nudnych-marek (dostęp: 05.01.2016).

5. Korach T. (2015), E-mail marketing jako nośnik content marketingu, www.tadeuszkorach.com/ e-mail-marketing-jako-nosnik-content-marketingu (dostęp: 29.12.2015).

6. Kubik A. (b.r.), Content marketing distribution mix, czyli jak skutecznie dystrybuować treści, www.o-m.pl/artykul/395/content-marketing-distribution-mix-czyli-jak-skutecznie-dystrybuowactresci.html (dostęp: 05.01.2016).

7. Maczuga P., Sikorska K. i in. (2014), Podręcznik do Content Marketingu. Proste sposoby na zmiane twojego podejścia do marketingu, Content Marketing Expert, Warszawa, www.cmex.eu/wp-content/uploads/2014/11/CMH_PL_www.pdf (dostęp: 05.01.2016).

8. MarketingProfs (2015), B2B Content Marketing 2016 Benchmarks, Budgets and Trends North America, www.contentmarketinginstitute.com/wp-content/uploads/2015/09/2016_B2B_ Report_Final.pdf (dostęp: 08.01.2016).

9. Oruba N. (2014), Silny odmieniec, czyli Inbound Marketing, www.norbertoruba.natemat.pl/ 128985,silny-odmieniec-czyli-inbound-marketing (dostęp: 05.01.2016).

10. Potępa M. (2015), Trendy w marketingu 2015 - postaw nowe cele!, www.thenets.pl/blog/ trendy-w-marketingu-2015-postaw-nowe-cele (dostęp: 05.01.2016).

11. Strykowski P., Kamińska P. (2015), Historia content marketingu, www.whitepress.pl/ userfiles/_CMS_/contentmarketing2015/ebook-historia-cm.pdf (dostęp: 28.12.2015).

12. Velocity 2012, The Content Marketing Strategy Checklist, www.velocitypartners.com/wpcontent/uploads/2012/06/Content-Marketing-Strategy-Checklist-Velocity-Partners.pdf (dostęp: 03.01.2016).

13. Winter T. (2014), Dowiedz się, jak stworzyć fabrykę Content Marketingu, www.inboundmarketing.pl/2014/07/dowiedz-sie-jak-stworzyc-fabryke-content-marketingu-infografika (dostęp: 05.01.2016).

14. www.contentmarketinginstitute.com (dostęp: 08.01.2016).

15. www.lego.com/pl-pl/friends (dostęp: 09.01.2016).

16. www.redbulletin.com/int/en (dostęp: 08.01.2016).

17. Zys D. (2012), Inbound marketing - strategia przyszłości, www.sprawnymarketing.pl/ inbound-marketing-strategia-przyszlosci (dostęp: 05.01.2016). 


\title{
CONTENT MARKETING AS ONE OF THE KEY ELEMENTS OF MODERN MARKETING STRATEGY
}

\begin{abstract}
Dynamically changing environment affects the development of existing and development of new strategies and - consequently - marketing techniques. One of them is content marketing, which involves creating unique content for the selected target group of the foundation of two-way communication with customers. The purpose of this article is to indicate the content marketing as one of the key elements of modern marketing strategy, which implies the involvement and creating added value for potential customers. Theoretical reflection - web-based literary sources due to the small number of books on the subject - was enriched with a practical example of the effective use of this technique by companies which through appropriate - modern - marketing strategy can have very good competitive position.
\end{abstract}

Keywords: content marketing, inbound marketing, modern marketing strategy, business management 